\title{
Educating child practitioners: a (re)turn to the university disciplines
}

This is an Accepted Manuscript of an article published by Taylor \& Francis Group in Discourse: Studies in the Cultural Politics of Education on 07/01/2014, available online at: http://dx.doi.org/10.1080/01596306.2013.871235.

\section{Authors' short biographical notes:}

Joan Forbes is a Reader in Education at the University of Aberdeen. Her publications on teacher/therapist inter/professional practice, children's services, gender and education, and elite schooling draw on social theory and social and educational policy sociology. Dr. Forbes's most recent book is: The transformation of children's services: examining and debating the complexities of inter/professional working (Routledge, 2012), edited with Cate Watson.

Elspeth McCartney is a Reader in Speech and Language Therapy at the University of Strathclyde. Dr. McCartney has with colleagues undertaken a series of clinical trials investigating therapies for language impairment, and recent publications relevant to teacher/therapist inter/professional practice include Applied linguistics and primary school teaching (Cambridge University Press, 2011), edited with Sue Ellis.

\section{Educating child practitioners: a (re)turn to the university disciplines}

\section{ABSTRACT}

This paper delineates and analyses a specific disjunctive policy space in Scotland involving the current key children's social and educational policy agenda, 'GIRFEC', and a recent national report on teacher education the 'Donaldson Report'. In four main parts, the paper first introduces and applies in policy review and analysis a 
capitals frame to identify the policy-practice discontinuities currently inherent in the 'GIRFEC-child practitioner education' policy space, exemplified by the Donaldson Report. Then, the same capitals frame is applied to examine the capitals resources demanded in the particular 'child-child practitioner education' policy space previously delineated. Next, examples of policy disconnects amongst current child practice and practitioner education policy production and implementation, which warrant a concerted integrative cross-sector project to ensure coherent social and intellectual capital relations at all levels, are discussed. Finally, the paper calls for the governing professional registration bodies and universities involved in the education of child-sector practitioners to together engage in the re-design of university programmes underpinned by principles of transdisciplinarity and transprofessionalism. The methodology is policy sociology and policy text analysis.

Keywords: social and intellectual capital, children's public policy, children's practitioner education, policy discourses and practices, policy sociology

\section{Introduction}

Embracing social and multiple capitals theory (Bourdieu, 1986) this paper explores the current state of readiness of school-, child- and youth-sector agencies in Scotland to implement a far-reaching, cross-sector policy: Getting it Right for Every Child (GIRFEC) (Scottish Executive [SE], 2005; Scottish Government [SG], 2008a, - updated 2012a). Attention is on policy effects for child social justice in a national child social policy moment which foregrounds issues of efficiency and planning (Scottish Parliament [SP] 2013). The critical policy sociology methodological approach (Ozga's 
term in Ball, 1997) applies a capitals frame to locate child practitioner policy and its enactments in a specific national, economic, political, historical and socio-cultural context. Policy therefore, refers here both to specific policy document texts and to the wider discourses and practices involved in policy production and enactment processes (Lingard, 2013).

The focus in the paper is on analysis of an exemplary specific policy space opened by the recent development of an overarching children's services policy agenda in Scotland, GIRFEC (SE, 2005; SG, 2008a, 2012a), to understand 'child-child practitioner education' policy disjuncture. Located locally in the particular disciplinary-inter/professional and socio-cultural context of Scotland, analysis of current Scottish children's services transformations mirrors parallel policy and practice change occurring in other UK countries (DfES, 2004; OFMDFM; 2006; WAG, 2005; and see Moran, Abbott, \& O'Connor, 2009; Pugh, 2009) and sector transformations globally across the anglophone world (DoES, IE, 2001; US Congress, 2002; and see Butt and Gunter 2009; Crow, 2012).

It is important to note that child sector change is occurring in Scotland in parallel with the implementation of a new school curriculum, Curriculum for Excellence (CfE) (SEED, 2004; SG, 2008b; SG, 2009). A flagship national education policy encompassing both pre-school and school education, CfE enjoins not only attention to academic attainment and exam passes but 'enriched' forms of teaching for student wider achievement in schools and communities (ES, 2013). CfE charges all practitioners involved to enable all children and young people in Scotland regardless 
of dis/ability gender, ethnicity or social class to achieve their potential as successful learners, confident individuals, responsible citizens and effective contributors (SEED, 2004 et seq.).

The paper takes the view then that the GIRFEC and CfE policy agendas are not incompatible; rather that both and together mobilize culture change that is - or should be - integrative across the child sector. Discourse in both GIRFEC and CfE policy characterises a new form of 'extended' professionalism. Accordingly, school teachers are enjoined to implement a single-, multi-, and inter- agency 'National Practice Model' (SG, 2012a). This, a model which moves education co-/practice beyond almost solely privileging scholarship and academic attainment measured by examination success (Paterson, 2003) towards co-/responsibility to address the diverse needs and abilities of children; to understand each child's 'whole world' experience, the connections between the different parties of their life-wide experience, and to monitor each child's well-being and resilience to adverse life circumstances and experiences (SG, 2012a).

GIRFEC and CfE do perhaps constitute atypical discourses and education policy enactments, in being intellectually and professionally outwardly-looking. The Scottish education policy community, small in number, has elsewhere been deemed to hold distinctive shaping values and traditions constitutive of policy with a 'conservative edge' (Raffe, 2004, unpaginated). Scottish policy historically has been depicted as viewing 'education as... teachers transmitting subject knowledge in formal institutions, and especially in schools'. The Scottish policy community has 
been considered to be 'more accepting of [prevailing] institutional structures and curricula' (ibid., 2004, unpaginated, parenthesis added; and see Paterson, 2003). Thus socio-culturally, a local national education political economy and social and educational policy tradition, while more 'outward looking and European in perspective' [than the other UK countries], has not, hitherto, viewed education either concerned with children's learning beyond academic subjects, or viewed schools as interdependent with other child sector institutions (Raffe, 2004, unpaginated; and see ibid. for fuller discussion of the Scottish cultural and institutional inflection of policy). It is in this discursive formation, then, that both CfE and GIRFEC represent attempts to change the culture and practices of schools and teachers within services for children.

Located in this global- local child and youth policy-practice space the paper explores ideas about the professional preparation needs of the children's workforce, debate about workforce 'modernisation' and 'remodelling' and the subject disciplinary and practice context specific knowledge and skills bases of child practitioners a focus of keen discussion and of policy transfer and borrowing not only in the UK countries, but in other places globally (Butt \& Gunter, 2009; and for fuller discussion of 'travelling policy' see Alexaidou and Ozga, 2002). Attendantly, the paper explores the politics of teacher education, the (re)location of teacher preparation in universities, and the responsibilities of universities for the effective professional education of future children's sector practitioners - not only of future school teachers but a wider children's practitioner education agenda. Thus, the paper raises questions of interest 
and importance for other children's edu-health-care systems and the university institutions which prepare these workforces internationally.

Analysis of the higher education requirements for each child profession is beyond the scope of the paper: accordingly, a recent report on teacher education is used as an example. The product of a major national review, an influential mono-disciplinary teacher education policy text is currently being enacted in/through monodisciplinary processes (the 'Donaldson Report' [SG, 2011a], introduced fully below). In contrast, a major child policy text, GIRFEC (SG, 2012a), and its processes and enactments enjoin transdisciplinary working. The product of this policy text disjuncture is, we argue, a child practitioner education - and practice - space, which is inherently incoherent. It should be noted here that our purpose is not to argue for either a mono- or trans- professional approach but rather to critically question this discursive milieux of governance and policy. Eschewing acceptance as 'self-evident' or 'common-sense' of 'policy-based evidence' (Tombs \& Whyte in Sanderson, 2004) on either side of the non/integration debate, we seek to carefully identify and analyse the discursive formations pertaining to each, examine their assumptions and incoherencies, and thereafter do not seek a 'solution' but the specification of an adequate intellectual agenda for more productive child practitioner identities and spatio-temporal relations (Watson \& Forbes, 2012).

Evaluation by the schools inspection body, Education Scotland (ES, 2012, p. 8), acknowledged this policy disconnect, reporting 'disjointed and poorly coordinated responses' across a number of dimensions of services' joint working approaches. Providing the necessary analytical purchase, a relational conceptual frame of social 
capital is now introduced and subsequently applied to uncover and analyse policy production and implementation disjunctures concerning the 'GIRFEC-Donaldson Report', child-child practitioner education policy.

\section{Applying a capitals relational frame}

Initial review of key policy texts relevant to the notion of the child at the centre of children's public policy (GIRFEC, SG, 2012a) and related to children's practitioner education (Donaldson Report, SG, 2011a) suggests that teaching and teacher education remain relatively impervious to the overarching social and educational policy demand for collaborative and integrative courses of action in child and young people settings. To analyse this perceived relational disconnect further here we draw on capitals theory, a frame for which is now introduced.

\section{Capitals Theory}

Informing public policy production (UKGPIU, 2002), social capital theory provides a necessary conceptual frame to understand and analyse practitioners' relational capabilities. Putnam (2000) identifies sub-types of social capital relations: bonding (exclusive of others not in home group, here professional group); and bridging (inclusive of non-professional group individuals). Putnam (2000,p. 22) notes that bonding relations may be more 'inward looking and have a tendency to reinforce exclusive identities and homogenous groups', while bridging relations are 'outward looking and encompass people across different social cleavages'. A third relational sub-type, linking - connecting people at different hierarchical levels - provides further analytical purchase (see Woolcock, 1998). Intersecting the sub-types axis are 
the concepts of social networks, social norms and social trust. Network connections based on shared norms and trust are viewed as valuable social and economic resources for individuals and society (Bourdieu 1986; Coleman, 1988; Putnam, 2000). Finally, the concept of human capital, the intellectual 'stock of expertise accumulated by a worker' (Halpern, 2005, p. 4; Coleman 1988), is analytically helpful to understand the individual-level practitioner knowledge and skills resources required in different co-practice inter/professional work relations, and applied by individuals to further build their social capital. We draw on the research of Gibbons, Nowotny and colleagues to introduce a further conceptual discrimination between subject disciplinary and practice context specific practical problem solving knowledge (Gibbons et al., 1994; Nowotny et al., 2003). Used previously by the present authors to examine co-working policy and governance, and policy enactments by individuals across sector institutions, this multi-level mapping is again applied here (see e.g. Forbes, 2008; 2012; Forbes \& McCartney, 2010; 2012a; 2012b).

\section{Applying a capitals frame to analyse relations in key policy}

Mono-professional reports: Donaldson and McCormac

A major review of teacher education in Scotland was commissioned by the Scottish Government, reporting in 2011: Teaching Scotland's Future: Report of a review of teacher education in Scotland (SG, 2011a, hereafter TSF). Chaired by Graham Donaldson, the review report is informally termed the 'Donaldson report'. An accompanying literature review: Literature Review on Teacher Education in the $21^{\text {st }}$ 
Century commissioned by the Scottish Government was also published (Menter et al., 2010).

In Scotland universities provide both initial (pre-service) and in-service teacher education. TSF (SG, 2011a) amongst other concerns addressed issues of partnership and collaboration - albeit almost exclusively issues of teacher education partnerships and collaborations within and between institutions across the education sector (Forbes \& McCartney, 2011). Indeed, GIRFEC policy is not cited in the Literature Review (Menter et al., 2010). Unsurprisingly then, the report does not recommend experience of cross-agency working in initial teacher education. Similarly, a National Partnership Groups (NPGs) (SG, 2011b, 2012b) convened following the report's publication, engaged mono-professionally in their deliberations on the report's enjoinders on career long, if not child-sector wide, professional learning. The NPG reported and disbanded in summer 2013, replaced by a National Implementation Board (NIB).

All Scottish university providers of Teacher Education, were represented on the NIB and contributed to its deliberations. Confirming the continued 'centrality' of university involvement in teacher education (SG 2011a p104), the Donaldson report made a number of recommendations which shift the locus of content and control of teacher education from university Schools of Education programmes, approved by the General Teaching Council Scotland (GTCS) on behalf of the Scottish Government, to a more mixed 'partnership' economy involving 'universities, local authorities, schools and individual teachers' in 'shared responsibility for key areas of teacher 
education' (SG 2011a p48). Centrally, the Donaldson report advocated 'schooluniversity partnership hubs ... for initial teacher education' and further recommended that these hubs 'continue to be developed to support learning for teachers at all stages in their careers' (SG 2011a, p10). Key here is that, paradoxically, given the thrust of current children's public sector policy on socially and intellectually integrative and connective, bridging and linking knowledge and skills sharing, the NIB retains a mono-disciplinary and mono-professional focus on 'the ... spectrum of teacher education' (SG, 2013, emphasis added).

Additional consideration of Scottish teachers' role appears in the Review of Teacher Employment (SG, 2011c, the 'McCormac Report'). Discussing teacher confidence and capacity, and invoking the new Scottish schools curriculum: Curriculum for Excellence (SG 2008b), the McCormac Report enjoins that:

the modern teacher must have an awareness of a whole series of policies and initiatives ranging from curricular change in the form of Curriculum for Excellence through to multi-service work under the [GIRFEC] banner. A teacher in Scotland not only needs the necessary skills and confidence to deliver a high quality education programme, but must also have the capacity to interact with the wider set of services responsible for the welfare of children' (SG, 2011c, p. 11, 2.7).

This statement, a succinct statement on 'Other Staff in Schools' (Section 8, pp. 4346), and a single recommendation on facilitating 'the involvement of external 
experts in the delivery of teacher-led school education' (Recommendation 31, p. 56) apart, the focus in the McCormac Report remains explicitly on teachers 'at the centre of an extended team of education professionals' (SG, 2011c, p. 45, 8.8), including a suggestion that the General Teaching Council for Scotland (GTCS) register 'vetted', 'external experts' (ibid. p. 45, p. 46). Again, a key report presents an almost solely teacher education perspective in a moment which demands that teachers, as other child practitioners, are qualified and equipped to work in interprofessional settings with children and young people. The McCormac Report recommendations remain to be finalised, but their mono-professional perspective sustains the status quo regarding teachers and 'Other Staff' in school settings.

Integrative policies: GIRFEC and Christie

Scotland subscribes to the United Nations Convention on the Rights of the Child (UN General Assembly, 1989), which ordains that education attends to children's wellbeing. Policies demanding cross-sector coherence and integration are invoked in GIRFEC, the Scottish social and educational policy agenda which enjoins coherent cross-agency action to address children's rights (SG, 2012a). And GIRFEC was enacted, rolled out, through local authorities in multi-professional contexts, rather than centrally, as for CfE. In the context of CfE policy enjoinders that the development of the requisite knowledge and skills for learning, life, and work for all children and young people is the responsibility of all practitioners, in schools and beyond (SG, 2009), current understandings of child wellbeing and welfare, and resilience as constituted within GIRFEC are being implemented in parallel with the Children and Young People (Scotland) Bill introduced in the Scottish Parliament in 
April 2013 (SP 2013, the Bill). All child agencies, including education, are charged to accept and implement the Bill, which includes a single planning process for the 'integrated' and 'efficient' provision of children's services in the way which 'best safeguards, supports and promotes the wellbeing of children in the area concerned' (ibid., p.7, 30-35). Thereby, intertwining discourses of efficiency with those of child social justice (cf. Ball, 1997).

Key, the Bill stipulates a common 'children's service plan', 'a document setting out ... plans for the provision over that period of all ... children's services, and ... related services' (SP, 2013, pp. 24-26). Concerted action across all children's services and agencies is specified, in order to fulfil a shared child-sector duty to work together to plan, deliver, manage and review policy and service with the aim of safeguarding, supporting and ensuring the wellbeing of children (SP 2013). These aims mesh with the desired outcomes of CfE: 'that all children and young people in Scotland develop the knowledge, skills and attributes they will need if they are to flourish in life, learning and work, now and in the future' (ES, 2013, unpaginated) and with GIRFEC policy: for children and young people to be active; respectful; responsible; included; safe; healthy; achieving; and nurtured (SG 2012a). To these ends, the course of action demanded of all child/youth public bodies, agencies and services is to secure for Scotland's children: the 'Best start in life: Ready to succeed' (ES 2012, 12). Thus, recent Scottish policy activity around the child enjoins practitioners to act together to ensure that the needs of each and every child are met in the round. A corollary of which, we argue, is that the associated inter-disciplinary and professional 
identifications be formed in/through initial practitioner education, and career-long thereafter.

In response to the challenges of unprecedented demographic change and rising demand facing public services in Scotland in a period of economic downturn (i.e. driven by an economising agenda, cf. Ball 1997), the Scottish Government commissioned a report on The Future Delivery of Public Services (SG, 2011d, the 'Christie Report'). This takes an integrative perspective towards professionalism, recommending a radical redesign and reshaping of public services including services' integration and mergers; and, relevant here, the implementation of 'new interagency training to reduce silo mentalities, drive forward service integration and build a common public service ethos' (ix).

\section{Education and GIRFEC}

Following earlier inspections which found that interprofessional collaboration was not being enacted as envisaged in policy (HMIE, 2009; HMIE, 2004) an evaluation by Education Scotland (ES, 2012), the national government school inspection agency, of the readiness of the education system to implement GIRFEC notes that Local Authorities, which manage schools in Scotland (square brackets denote parentheses added),

are contributing to the strengthening of multi-agency working. In the best examples, collaborative working across education, health, social work, police and voluntary agencies is helping to facilitate prompt contact between 
agencies, enabling more efficient sharing of information, faster responses and thus help for children and families at the right time. (p. 5)

However, at school level, ES (2012) found limited evidence of cultural change towards unified approaches. There were examples of cross-agency working, but:

some schools view [GIRFEC] just as a process for accessing additional help for children and not as a way of working to ensure that all children and young people reach their full potential. (ibid., p. 3)

And so

The evidence from our visits to early years centres and schools shows that the [GIRFEC] approach is not yet being used consistently within establishments and across authorities. There is not a shared understanding of wellbeing and staff do not always recognise their responsibilities in promoting and supporting the wellbeing of children and young people. (ibid., p. 3)

ES (2012) recognises the importance of in-service education in implementing common approaches to service planning and delivery, but reports that:

in almost all authorities in the sample, there is no systematic, on-going training and development opportunities for education staff to help them 
understand and use the Getting it right approach. (ibid., p. 7)

The lack of multi-agency training means that school staff:

feel that they need to improve their understanding of the functions of other agencies and the roles and responsibilities of colleagues working in them. (ibid., p. 8)

The conclusion is that:

Education authorities demonstrate a firm commitment to joint working approaches with other services and agencies. However, the differences in the ways that the services operate means that children, young people and their families do not always experience the quality of support that they need to enable them to be the best that they can be. For example, the different ways that services are designed and the different approaches they use to plan and assess young people's needs, to record and share information and the different language and processes they use, can result in children and families experiencing disjointed and poorly coordinated responses to their needs. Across the universal services and other agencies working with children, there is no shared interpretation of well-being. (ibid., p. 8)

Of related concern, in the context of the Donaldson report recommendation that a limited number of schools should be involved in initial teacher education [ITE] (SG 
2011a), is that the culture that develops in these new teacher education universitylocal authority 'ITE hub' schools is not mono-professionally inward looking; and of equal concern is that schools with exemplary joined-up children's services cultures and may not be involved in ITE and concomitant rich opportunities for student teachers' early inter/professional enculturation.

\section{The specific GIRFEC-TSF space applying a capitals frame}

Review and analysis of policy focusing on 'child-child practitioner' relations then, demands re-designed bridging and linking knowledge and social relations. Therefore three specific questions now inform discussion of the particular TSF (SG, 2011a) and GIRFEC (SG, 2012a) policy texts, and of the relations enactments needed in this particular 'child-child practitioner education' policy space:

- how are inter/professional social and intellectual capital relationships characterised in the TSF text?

- how do GIRFEC policy texts constitute inter/professional social and intellectual capital relations, knowledge and skills relations?

- and subsequently, what further bridging and linking social and intellectual capitals, knowledge and skills relations between the child-sector and its educators in universities need to be enacted to 'get right' future co-practice across the entire children's public sector space in Scotland? 
As indicated above, TSF (2011a) lost a key opportunity to examine and understand the effects of wider supra-national and national policy and legislation which, we argue, demand that teacher initial and career-long education forge bridging and linking relational knowledge, capabilities, and practitioner identities. Paradoxically, TSF production and enactments hark back to the era of within-profession bonding capitals, characterised by stand-alone schools and education departments: a monosystem considered to have ended with the advent of a New/Integrated Community Schools agenda at the turn of the millennium (Scottish Office, 1999). Failing to reference the GIRFEC agendas, TSF policy production did not and could not fully understand teacher co-practice capabilities enacted in GIRFEC, e.g. for child wellbeing and a holistic approach to the child, nor demand that teacher education act to ensure such practitioner capabilities and identities.

\section{Social and intellectual capitals in GIRFEC}

The GIRFEC policy agenda demands strong bridging and linking forms of interprofessional practice relations across the child sector, both for efficiency and for a turn to social justice. However, whilst enjoining action to reform and strengthen bridging and linking social and intellectual connections across all child-sector professional groups and agencies, those involved in GIRFEC production omitted to look upstream in the child practitioner education system. Thus, concomitant courses of action upstream to better join up and integrate practitioner initial and continuing education in order to address incoherence across the sector were neglected, and a moment for cross-sector reformation of practitioner education was lost. 
Analysis identifies however that the Children and Young People (Scotland) Bill (SP, 2013) and GIRFEC: Where are we now? evaluation (ES, 2012) do now fully and explicitly recognise a number of the difficulties experienced across education in enacting the GIRFEC practitioner joint working agenda (health and social services are not considered in the 'child-child practitioner education' exemplification here).

For example ES $(2012$, p. 9) concludes that for education to fully enact the GIRFEC agenda, education 'authorities' and school 'establishments' 'need to continue to work closely with other services and take action to:

- Develop a shared understanding of wellbeing and that it is everyone's responsibility to promote and support the wellbeing of every child and young person.

- Facilitate training for all staff to support effective delivery of the roles of Named Person and Lead Professional and the use of the National Practice Model (key features of GIRFEC approaches).

- Agree and implement a single planning process.

- Establish more meaningful partnership working with parents including helping them to know about the Getting it Right approach.

- Actively promote and demonstrate Getting it Right approaches across their council area. 
Thus, change in social and intellectual partnership and collaboration is prescribed across the new GIRFEC policy enactment space at different levels: at the level of institutions' policy and governance production; at the level of co-practice across children's institutions; and at the individual practitioner level in necessary new learning about e.g. 'child wellbeing', 'child protection', 'safeguarding', 'the rights of children and young people', 'support' applying the GIRFEC-initiated 'National Practice Model', and about new 'more meaningful' forms of 'partnership with parents'. If education services become equipped to participate securely and confidently in carrying out GIRFEC approaches in their co-practice (ES 2012, p. 9), increased enactments of bridging and linking social capital, and new knowledge, should be products.

However, policy enjoinders produced by, and directed towards, educational services alone, do not challenge a bonding mono-professional and mono-disciplinary educational perspective, and indeed tend to represent and legitimate it. This continues to elide - and so 'other' - non-education authorities, establishments, knowledge and practices (Forbes \& McCartney, 2010). Indeed, reporting on the 'readiness of the education system' (ES, 2012) evidences that governance and policy protagonists of the GIRFEC agenda themselves do not view all child/youth sector practitioners and their home agencies across children's services as the target audience for their messages. For non-education practitioners and agencies, this reduces or removes a professional - and ethical - responsibility to enact joined-up governance and policy directives, or to acquire the forms of bridging and linking relational knowledge and skills capabilities policy demands. 


\section{Findings discussion}

1) Knowledge and skills relations: from 'bonding' to 'bridging' and 'linking' 'mono' to 'inter' and 'trans' perspectives

As stated, TSF (SG, 2011a) set out a mono-professional view of the future professional education needs of teachers, with very little consideration of the wider edu-health-care policy and practice assemblage in which teachers and education now must collaborate with colleagues and partner other institutions (SG, 2012a).We argue that the resulting mono-professional educational experiences and relationships engendered will continue to lead to the lack of understandings amongst school staff identified in ES (2011) above.

As an alternative, we would argue that the future of child practitioner education must be more complex. Enactment of current socio-economic and social justice, policy around the child demands innovative, influential and ambitious crossdiscipline research-led teaching. One driver in the post-TSF context is likely to involve school-teacher education moving towards a Master's degree qualification and more widely available opportunities than currently for career-long M-level learning. TSF recommended that Masters level learning be the norm for entry to the profession and that M-level credits be made available where possible, albeit stopping short of recommending a fully Masters qualified teaching profession (TSF, SG, 2011a). From 2012 all Scottish ITE provider universities (nine universities now including the Open University in Scotland and the University of the Highlands and Islands) commenced phasing out the traditional Bachelor of Education (BEd) degree 
entry route, developing a range of successor degree qualifications, generally either BA (Hons.) or MA (Hons.), combining professional studies with in-depth academic study in university subject areas beyond the field of education (SG 2012b). Together, moves towards M-level learning and wider university involvement in ITE qualifications may provide a necessary intellectual and social space to re-design inter/professional education better connected to the GIRFEC agenda.

M-level initial practitioner education programmes could provide the interprofessional knowledge and skills learning necessary for competent and confident practitioners equipped to enact a connective cross-services approach to individual child/youth needs, rights and wellbeing, thereby enacting GIRFEC and related child social and economic policy. This course of action in tandem challenges relevant professional bodies, employers, and Scottish universities to endorse and provide cross-disciplinary Masters programmes for sector-wide practitioner education that aims to achieve child social justice - and not, as exemplified in TSF, solely mono-professional Master-teacher education.

In recent evaluation, policy and legislative texts Education Scotland (2012), the Scottish Government (2012a), and Scottish Parliament (2013) point to disjunctures not only systemic, and in policy and practice, but cultural, concerning core crosscutting social justice concepts such as 'safeguarding', 'wellbeing' and 'children's rights' which require to be fully understood rather than superficially addressed. This reinforces the case for practitioners' preparatory university education to be underpinned by the principle of transdisciplinarity. This demands a more integrated 
relationship between subject disciplinary theory and interprofessional practice, and between university and children's professions practitioners. TSF [SG, 2011a] for example, recommends university/schools joint posts). It would also demand redesigned relations amongst university practitioners involved in initial child/youthpractitioner education. Re-design demanding thoughtful, focused, re-examinations by university teachers of their current understandings and applications of pedagogical and practice content knowledge. The introduction of a Master's degree as a route to practice for [school] teachers may support the conclusion that other child sector professions equally have the opportunity of research-led Masters level intellectual education.

Transdisciplinary education to Master's level as the pre-service norm would require universities fundamentally to re-conceptualise their cross-institutional role and efforts for child public sector practitioner education. It would demand re-design across university disciplinary areas (and related institutional structures) to support new sector-facing disciplinary bridging and linking knowledge and skills networks for the interprofessional education of future child/youth sector practitioners. University re-structuring for transdisciplinary teaching and research for practice will be needed to realise this perhaps once-in-a-generation opportunity to produce competent and confident practitioners around the child able to adopt a coordinated and unified approach to 'identifying concerns, assessing needs and agreeing actions and outcomes based on Wellbeing Indicators', working jointly and communicating in the field of children's services (ES, 2012, Appendix 1, 11). 
2) Interdisciplinary knowledge and skills relations: creating confident, competent interprofessional practitioners

Fundamental to the creation of 'a competent workforce across all services for children, young people and their families' is the creation of practitioners who feel not only 'skilled' but 'confident' (ES, 2012, Appendix 1,p.11). Practitioner confidence (a key term in social capital theory alongside trust) requires an initial professional education not only in subject disciplinary knowledge, categorised as Mode 1 subject disciplinary knowledge by Gibbons et al. (1994) and Nowotny et al. (2003), but also in being educated, fully prepared and well-equipped to understand and apply practical, work context specific problem solving knowledge, what Gibbons and colleagues term Mode 2 knowledge. This, we would argue, demands future practitioners that fully understand changed context-specific co-work for child social justice, and the novelty and inherent ambiguities of this cross-sector linked and connected work. Thus, the current post-TSF National Implementation Board discussions need to debate, examine and report on the knowledge and skills needed by practitioners in the sector (including school teachers) to operate as confident, inter/disciplinarily accomplished and inter/professionally equipped assured agents for child/youth 'well-being' (ES, 2012).

Critically, given the need for cross-sector practitioner confidence and agentic competence (ES, 2012, Appendix 1, p. 11), an inter-disciplinary project is now needed in teaching and research in Scottish universities involved in child practitioner education. The need is to develop Scotland's future child practitioners as Scottish public intellectuals who work across professional boundaries and across the two 
axes of research/practice and identities/knowledges (both disciplinary and practical, problem solving child-sector specific modes) (Gibbons et al., 1994; Nowotny et al., 2003) to fashion themselves as active, competent and confident agents for child/youth social justice and wellbeing (ES, 2012) (see e.g. the Teacher in Public local intellectual initiative, University of Aberdeen, 2013a).

3) Knowledge and skills relations: towards transdisciplinary identifications Ambitious in its scope, such a whole-scale (re)education project across relevant university disciplines could change the knowledges and identities, minds and hearts, of future child-sector practitioners, and offer the means to galvanise the full potential of the raft of thoughtful and rich policy and research on the task to date. Bridging and linking interdisciplinary education for teachers, and indeed for child/youth practitioners, from the pre-service professional education stage is a direct corollary to enact GIRFEC and Scottish Curriculum for Excellence (SG, 2008b) policy texts' aims of: shared understanding; agreeing actions and outcomes; cooperation; co-ordinating activity across boundaries; via a confident and competent workforce (ES, 2012).

\section{Conclusions}

TSF (SG, 2011a) recommended a large number of changes for teacher education and education, but its authors were not charged to, and so did not, undertake the necessary wholescale cross-sector review of the practitioner, knowledge types, skills and relational capabilities for child social justice and wellbeing, nor consider the concomitant course of action for practitioner education they demand. 'Wholescale', 
we feel, captures the scale of review and re-design needed to effect transformative bridging and linking knowledge and skills connections and associated relational capabilities across all levels of the child-sector - practitioner, institutional, governance - and address the concomitant sector-wide cross-disciplinary university learning re-design.

Such a wholescale review, in the sense of scrutiny of the re-arrangements of governance, children and youth institutions, and critically here, involving the universities which educate the children's workforce, is long overdue. We have argued elsewhere (Forbes \& McCartney, 2011; 2012b) that governance and systems levels should have been reviewed for their 'fitness-for-purpose' prior to enactment of earlier integrated services policy (e.g. The Prospectus, SO, 1999). To enact GIRFEC proposals on services' integration and interprofessional working, we argue that an early review of practitioner education across the wider children's public sector is needed to re-balance the systems and structures disconnects identified in the Education Scotland evaluation (2012) and the Scottish Parliament Child and Young People (Scotland) Bill (2013). We would add to this list the social and intellectual capitals disconnects identified here. Review of the skills and use of the public workforce resource is particularly urgent in the current and socio-economic moment of long-term political discourses of restraint in public service funding.

\section{Some specific suggestions}

Practitioner (re)education in 'common approaches' is currently predominantly undertaken in-service, and mainly in the form of inputs on 'joint working', and is 
demonstrably not working. Accordingly, we suggest, a more radical approach focusing on pre-service education and practitioners' pedagogical experiences in initial university-based undergraduate studies justifies exploration.

The challenge articulated is to transform transdisciplinary connections as a priority across the university disciplines which educate children's practitioners (Forbes, 2012). A focus on the space of research on professionalism, society, and pedagogical innovations would re-build the currently weak cross-discipline and cross-profession bridges and links. New, stronger, reciprocal networks, norms and trust would be developed, involving all disciplines from inception and not 'essentialising' education - as occurred in recent policy and its proposed enactments (ES, 2012; SP, 2013) - and which has proved unacceptably complex and disjunctive in enacting GIRFEC policy.

As a first step, university-based teaching that draws on the knowledge of relevant research traditions is needed to bridge and link intellectually across child-sector practitioner education disciplines. This is not a new idea, but rather a return with a new purpose and emphasis to the foundation or sub-disciplines that underpinned child (including teacher) professional education in previous eras: psychology, philosophy, history, sociology, politics and policy study (McCulloch, 2012). These and other disciplinary knowledge bases related to e.g. child wellbeing now need to be drawn upon to adequately enact GIRFEC policy. That agenda, we conclude, demands both a (re)turn to educational foundation disciplines; and a broadening crossuniversity education for child-sector practitioner groups: the allied health professions, social work; youth justice; policing, child health, nursing and dentistry to 
name but some. Common issues might include aspects of social justice and societal inclusion; networked professional relations; understandings of how children and young people develop and learn and how communication may be fostered; biopsycho-social models of disability, and their systems of thought and evidence.

Recent review of university curriculum content and processes of teaching and learning support, designed to deliver a curriculum suited to the economy and society (Vidovich, O’Donoguhue \& Tight 2012) and strengthening university-community partnerships, points to efforts in/by the academy to enact effective child practitioner pedagogy - teaching and learning support. A critical necessity is to raise awareness of the need for cross-university disciplinary knowledge and skills connections that adequately prepare Scotland's current and future child-sector practitioners for practice from the outset in a sector which is now envisaged by the Scottish Government (2012a) as transprofessional at all levels - policy and governance, institutions and practice. These demand a workforce which itself thinks across previous agency and professional boundaries (Forbes, 2012).

It is timely that all involved embark on serious and sustained 'researcherly' conversations to identify common research interests pertaining to 'the child' at the intersections of pedagogical innovations, professionalism, and societal demands for better service integration (SG, 2011d). Illustrative examples of different universities willing to address the wider practitioner research include the Aberdeen Forum for the Child (University of Aberdeen, 2013b), a joint research initiative of Aberdeen and Robert Gordon universities; the Glasgow Centre for the Child and Society, a joint 
research initiative between the Universities of Glasgow and Strathclyde (University of Strathclyde, 2013); proPEL a multi-professional research and knowledge exchange network at the University of Stirling (University of Stirling, 2013); the University of Edinburgh Child Development and Wellbeing research theme (University of Edinburgh 2013); and the University of the West of Scotland [UWS] Institute for Youth and Community Studies (UWS, 2013). While the institutional structures of universities such Dundee, where Education is co-located with other child sector disciplines in an integrated School of Education, Social Work and Community Education, equally signal universities' commitment to the creation of durable intellectual inter/disciplinary spaces to address the wider practitioner education and research agendas.

Such transdisciplinary research forums that focus on building knowledge about the child', 'youth' and 'childhood' need to be further developed and supported interinstitutionally and nationally. Innovative research groupings around the child should stimulate transdisciplinary knowledge exchange practices and institutionalise the types of sustained and well resourced transdisciplinary research and knowledge production and associated pedagogical innovations needed to transform radically the delivery of children's services. All child and family facing disciplines must be equally concerned with the production in/through teaching and research of 'good' graduates - effective, confident and competent networked intellectual workers for child social justice. 
In summary therefore this paper has identified policy inattention to the good coeducation of child-sector practitioners and highlighted concomitant problematic disjunctures in the sector that flow from the current separate education of childsector professionals for co-practice, which now ought to be addressed in and through a course of action involving:

1) a focused, rigorous audit and review of governance and policy directed at all professional groups across the child-sector, to understand what bridging and linking social and intellectual capitals, knowledge, skills and co-work relational capabilities, are required;

2) the institution of policy production arenas and processes aimed to deliver coherent, continuous and connected cross-profession and cross-agency policy texts and policy enactments underpinned by values of child wellbeing and social justice;

3) as practitioner re-education needs for effective inter- and trans-professional working become understood, working with the university institutions involved to re-design practitioner education programmes. These, taking full account of learning about good child justice focused enactments of GIRFEC and associated policy, aimed to educate practitioners in the necessary transdisciplinary knowledge, skills and relational capabilities for child-sector co-practice;

4) a clearer understanding by government agencies, professional registration bodies and university disciplines who design and implement practitioner initial and careerlong education that to achieve an overarching child policy vision of social justice the child-child practitioner education policy space must be informed by a conceptual framework that is transprofessional and transdisciplinary in nature. 


\section{References}

Alexaidou, N. \& Ozga, J. (2002). Modernising education governance in England and Scotland: devolution and control. European Educational Research Journal, 1(4), 676690.

Ball, S.J. (1997). Policy Sociology and Critical Social Research: a personal review of recent education policy and policy research. British Educational Research Journal, 23(3), 257-274.

Bourdieu, P. (1986). The forms of capital. In J.G. Richardson (Ed.), Handbook of theory and research for the sociology of education (pp. 241-258). New York, NY: Greenwood.

Butt, G. \& Gunter, H. (2009). Modernising and remodelling schools: are there 'global solutions' to transforming the school workforce? In J. Forbes \& C. Watson (Eds.) Service integration in schools: research and policy discourses, practices and future prospects (pp145-156). Rotterdam: Sense Publishers.

Coleman, J. (1988). Social capital in the creation of human capital. American Journal of Sociology. 94 (Suppl.), S95-S120.

Crow, G. (2012). Professional identities: developing leaders for inter/professional practice. In Forbes J. \& Watson, C. (Eds.) The transformation of children's services: 
examining and debating the complexities of inter/professional working (pp92-104). London: Routledge.

Department for Education and Skills (DfES). (2004). Every child matters: change for children. London: DfES.

Department of Education and Science, Social Inclusion Unit, Republic of Ireland (DoES, IE). (2001). Giving children an even break by tackling disadvantage in primary schools. Dublin: The Stationery Office.

Education Scotland [ES] (2013). What is the curriculum for excellence? The purpose of the curriculum. Retrieved 19 August 2013 from http://www.educationscotland.gov.uk/thecurriculum/whatiscurriculumforexcellenc e/thepurposeofthecurriculum/index.asp

Education Scotland (ES) (2012). Getting it Right for Every Child: Where are we now? A report on the readiness of the education system to fully implement Getting it right for every child. Livingston: Education Scotland. Retrieved 21 June 2013 from http://www.educationscotland.gov.uk/inspectionandreview/Images/GIRFEC\%2OFIN AL\%2024-10-12 tcm4-735258.pdf

Forbes, J. (2008). Knowledge transformations: examining the knowledge needed in teacher and speech and language therapist co-work. Educational Review, 60 (2), 141154. 
Forbes, J. (2012). Transprofessional social capital in children's services: dis/connects in policy and practice. In J. Forbes \& C. Watson (Eds.), The transformation of children's services: examining and debating the complexities of inter/professional working (pp. 40-51). London: Routledge.

Forbes, J., \& McCartney, E. (2010). Social capital theory: a cross-cutting analytic for teacher/therapist work in integrating children's services? Child Language Teaching and Therapy, 26(3), 321-334.

Forbes, J., \& McCartney, E. (2011). Educating Scotland's future together? Inter/professional education for schools and children's services. Scottish Educational Review, 43(2), 39-54.

Forbes, J., \& McCartney, E. (2012a). Changing children's services: a social capital analysis. In M. Hill, G. Head, A. Lockyer, B. Reid and R. Taylor (Eds.), Children's Services: Working together (pp. 275-287). Harlow: Pearson.

Forbes, J., \& McCartney, E. (2012b). Leadership distribution culturally? Education/ speech and language therapy social capital in schools and children's services, International Journal of Leadership in Education. 15(3), 271-287.

Gibbons, M., Limoges, C., Nowotny, H., Schwartsman, S., Scott, P. \& Trow, M. (1994). The new production of knowledge. London: Sage. 
Halpern, D. (2005). Social Capital. Cambridge: Polity Press.

Her Majesty's Inspectorate of Education (HMIE) (2009). Improving Scottish education: A report by HMIE on inspection and review 2005-2008. Livingston: HMIE.

Her Majesty's Inspectorate of Education [HMIE] (2004). The sum of its parts? The development of integrated community schools in Scotland. Edinburgh: HMIE.

Lingard, B. (2013). The impact of research on education policy in an era of evidencebased policy. Critical Studies in Education. 54(2), 113-131.

McCulloch, G. (2012, October). The study of education: the making of a multidisciplinary field. Paper given at the Society for Educational Studies 2012 Seminar Series: The social organisation of educational studies in Scotland and England: Past, present and future, University of Stirling, Stirling, Scotland.

Menter, I., Hulme, M., Elliot, D. \& Lewin, J. with Baumfield, V., Britton, A., Carroll, M., Livingston, K., McCulloch, M., McQueen, I., Patrick, F. \& Townsend, T. (2010). Literature Review on Teacher Education in the $21^{\text {st }}$ Century. Edinburgh: Education Analytical Services, Scottish Government.

Moran, A., Abbott, L. \& O'Connor, U. (2009) Communicating, coordinating and connecting: integrated service provision in Northern Ireland. In J. Forbes \& C. 
Watson (Eds.) Service integration in schools: research and policy discourses, practices and future prospects (pp65-76). Rotterdam: Sense Publishers.

Nowotny, H., Scott, P. \& Gibbons, M. (2003). Mode 2 revisited: The new production of knowledge. Minerva, 41, 179-194.

Office of the First Minister and Deputy First Minister (OFMDFM) (2006) Our children and young people: our pledge. A ten year strategy for children and young people in Northern Ireland, 2006-2016. Belfast: OFMDFM.

Paterson, L. (2003) Scottish Education in the Twentieth Century. Edinburgh: Edinburgh University Press.

Pugh, G. (2009) Every child matters: the implications for service integration in England. In J. Forbes \& C. Watson (Eds.) Service integration in schools: research and policy discourses, practices and future prospects (pp77-92). Rotterdam: Sense Publishers.

Putnam, R.D. (2000). Bowling alone: the collapse and revival of American community. New York, NY: Simon \& Schuster.

Raffe, D. (2004) How distinctive is Scottish education? Five perspectives on distinctiveness. Scottish Affairs, 49(Autumn), unpaginated. Retrieved 18 August 2013 from http://www.scottishaffairs.org/backiss/pdfs/sa49/sa49 Raffee.pdf 
Sanderson, I. (2004). Getting evidence into practice. Evaluation, 10, 366-379.

Scottish Executive [SE] (2005). Getting it right for every child: proposals for action. Edinburgh: Scottish Executive.

Scottish Executive Education Department [SE] (2004). A curriculum for excellence. Edinburgh: Scottish Executive Education Department.

Scottish Government (SG). (2013). Teaching Scotland's Future - National Implementation Board. Edinburgh: Scottish Government. Retrieved 19 June 2013 from

http://www.scotland.gov.uk/Topics/Education/Schools/Teaching/CPD/Nationallmpl $\underline{\text { ementationBoard }}$

Scottish Government (SG). (2012a). Getting it Right for Children and Families. A Guide to Getting it Right for Every Child. Edinburgh: Scottish Government. Retrieved 21 June 2013 from http://www.scotland.gov.uk/Resource/0039/00394308.pdf

Scottish Government (2012b) Teaching Scotland's Future - National Partnership Group. Report to Cabinet Secretary for Education and Lifelong Learning. Retrieved 19 August 2013 from http://www.scotland.gov.uk/Resource/0040/00407756.pdf 
Scottish Government (SG). (2011a). Teaching Scotland's Future: Report of a review of teacher education in Scotland. Edinburgh: Scottish Government. Retrieved 21 June 2013 from http://www.scotland.gov.uk/Resource/Doc/337626/0110852.pdf

Scottish Government (SG). (2011b). Teaching Scotland's Future National Partnership Group: Membership. Edinburgh: Scottish Government. Retrieved 21 June 2013 from http://scotland.gov.uk/About/Review/NationalPartnershipGroup/Membership Scottish Government (SG). (2011c). Advancing professionalism in teaching: The report of the review of teaching employment in Scotland. Edinburgh: Scottish Government. Retrieved 21 June 2013 from

http://www.scotland.gov.uk/Resource/Doc/920/0120902.pdf

Scottish Government (SG). (2011d). Commission on the future delivery of public services. Edinburgh: Scottish Government. Retrieved 21 June 2013 from http://www.scotland.gov.uk/Resource/Doc/352649/0118638.pdf

Scottish Government [SG] (2009). Curriculum for excellence: building the curriculum 4. Skills for learning, skills for life and skills for work. Edinburgh: The Scottish Government. Retrieved 18 August 2013 from http://www.scotland.gov.uk/Resource/Doc/288517/0088239.pdf 
Scottish Government (SG). (2008a). A guide to Getting it Right for Every Child.

Edinburgh: Scottish Government. Retrieved 21 June 2013 from

http://www.scotland.gov.uk/Resource/Doc/238985/0065813.pdf

Scottish Government (SG). (2008b). Curriculum for Excellence: Building the

Curriculum 3. A Framework for Learning and Teaching. Edinburgh: The Scottish

Government. Retrieved 21 June 2013 from

http://www.scotland.gov.uk/Resource/Doc/226155/0061245.pdf

Scottish Government Social Research (SGSR). (2010). Literature Review on Teacher

Education in the $21^{\text {st }}$ Century. Edinburgh: Education Analytical Services, Scottish

Government.

Scottish Office (SO). (1999). New Community Schools. The Prospectus. Edinburgh:

Scottish Office.

Scottish Parliament (SP). (2013). Child and Young People (Scotland) Bill [As

introduced]. Edinburgh: Scottish Parliament. Retrieved 23 June 2013 from

http://www.scottish.parliament.uk/S4 Bills/Children\%20and\%20Young\%20People\%

$\underline{20 \text { (Scotland)\%20Bill/b27s4-introd.pdf }}$

UK Government Performance and Innovation Unit (UKGPIU). (2002). Social capital: $a$ discussion paper. London: Performance and Innovation Unit. 
United Nations General Assembly (UN). (1989). Convention on the rights of the child. General Assembly resolution 44/25 of 20 November 1989. Geneva: Office of the UN High Commissioner for Human Rights. Retrieved 21 June 2013 from http://www2.ohchr.org/english/law/pdf/crc.pdf

United States $107^{\text {th }}$ Congress. (2002). An Act to close the achievement gap with accountability, flexibility and choice, so that no child is left behind. This title may be cited as the 'No child left behind Act of 2001'. Public Law 107-10. Washington, DC: US Congress. Retrieved 29 July 2013 from:

http://www.2.ed.gov/policy/elsec/leg/esea02/107-110.pdf

University of Aberdeen. (2013a). Theory Space: Teacher in Public Initiative. Retrieved 30 June 2013 from http://www.abdn.ac.uk/dev-education/research/the-theoryspace-526.php

University of Aberdeen. (2013b). Theory Space: Aberdeen Forum for the Child. Retrieved 30 June 2013 from http://www.abdn.ac.uk/deveducation/research/aberdeen-forum-for-the-child-525.php University of Edinburgh (2013) Education Research: Child Development and wellbeing. Retrieved 20 August 2013 from http://www.ed.ac.uk/schoolsdepartments/education/rke/education-research/child-development-theme 
University of Stirling (2013) ProPEL: professional practice, education and learning.

Retrieved 19 August 2013 from http://www.propel.stir.ac.uk/about/

University of Strathclyde (2013) The Glasgow Centre for the Child and Society.

Retrieved 19 August 2013 from

http://www.strath.ac.uk/humanities/socialwork/glasgowcentreforthechildandsociet

$\mathrm{y} /$

University of the West of Scotland (2013) Institute for Youth and Community

Research. Retrieved 20 August 2013 from http://www.uws.ac.uk/schools/school-of-

education/research/iycr/

Vidovich, L., T. O’Donoguhue, and M. Tight. (2012). Transforming university

curriculum policies in a global knowledge era: mapping a "global case study"

research agenda. Educational Studies, 38(3), 283-295.

Watson, C. \& Forbes, J. (2012) Inter/professional children's services: complexities, transformations and futures. In J. Forbes \& C. Watson (Eds.), The transformation of children's services: Examining and debating the complexities of inter/professional working (pp183-194). London: Routledge.

Welsh Assembly Government (2005) A fair future for our children. Cardiff: The Welsh Assembly Government. Retrieved 29 July 2013 from:

http://wales.gov.uk/dsjlg/publications/childrenyoung/fairfuture/strategye?lang=en . 
Woolcock, M. (1998). Social capital and economic development: towards a theoretical synthesis and policy framework. Theory and Society, 27, 151-208. 